JCEBT, 3 (2) September 2019ISSN 2549-6379 (Print)ISSN2549-6387 (Online)

DOI: $10.31289 /$ jcebt.v3i2.2778

JCEBT

(Journal of Civil Engineering, Building and Transportation)

Available online http://ojs.uma.ac.id/index.php/jcebt

\title{
Pengaruh Penambahan Pecahan Kulit Kemiri Sebagai Pengganti Sebagian Agregat Kasar Pada Beton Terhadap Massa Dan Kuat Tekan Beton
}

\section{Influence Of Addition Of Hazelnut Shell Hardware As Substitute Of Reliable Agregate In Concrete To Mass And Strong Press}

\author{
*Dian Amri \& Irwan \\ Jurusan Teknik Sipil Fakultas Teknik Universitas Medan Area \\ Alamat:Jalan Kolam No. 1, Medan Estate, Medan \\ Diterima: 06-08-2019; Disetujui: 02-09-2019; DiPublish: 10-09-2019 \\ Email:amridian94@gmail.com
}

\begin{abstract}
Abstrak
Beton merupakan bahan yang banyak digunakan dan menjadi unsur utama pada bangunan. Kelebihan beton antara lain memiliki kuat desak yang tinggi dibanding kuat tariknya, mudah dibentuk, tidak memerlukan perawatan khusus, bahan susun mudah didapat dari alam sekitar, dan lebih awet dibandingkan bahan bangunan lain. Semakin banyak beton digunakan sebagai bahan penyusun struktur beton, maka mendorong penelitian untuk mengembangkan material maupun cara pembuatan beton. Kulit kemiri merupakan salah satu jenis partikel yang bobotnya sangat ringan dalam keadaan kering dan cukup keras.Dimana kulit kemiri itu sendiri dikenal sebagai limbah yang banyak tertimbun dan cenderung menjadi sampah karena pemanfaatannya yang masih sedikit atau relatif kecil, sehingga perlu ditangani secara serius.Selain itu, dewasa ini kulit kemiri hanya dimanfaatkan untuk sebagian kecil kebutuhan saja. Tujuan dari penelitian ini ialah untuk mengetahui kuat tekan beton serta memanfaatkan limbah kulit kemiri sebagai bahan tambahan beton sebanyak 10\%, 20\%, serta 30\% dengan mutu beton yang direncanakan K225, dengan umur rencana beton 28 hari, Penambahan kulit kemiri pada campuran beton mengakibatkan penurunan kuat tekan beton normal disetiap variasi persentasenya. Hal ini di sebabkan campuran kulit kemiri tidak cukup kuat untuk menjadi pengganti agregat kasar, sehingga mengakibatkan penurunan kuat tekan beton.
\end{abstract}

Kata kunci: Beton, Kulit kemiri, Kuat tekan Beton

\begin{abstract}
Concrete is a material that is widely used and become a major element in the building. The advantages of concrete, among others, have a strong high pressure than the tensile strength, easily formed, does not require special care, the material is easy to obtain from the surrounding, and more durable than other building materials. The more concrete is used as the constituent material of the concrete, hence encouraging research to develop the material as well as the way of making concrete. Hazelnut shell is one type of particle that is very light weight in a dry and quite hard. Where the hazelnut shell is it self known as a lot of waste accumulated and tend to become garbage because its utilization is still small or relatively small, so it needs to be handled seriously. In addition, today hazelnut shell is only used for a small need only. The purpose of this research is to find out the compressive strength of concrete and to utilize the waste of hazelnut shell as 10\%, 20\% and 30\% concrete additives with the planned K225 concrete quality, with 28 days concrete plan, The addition of hazelnut shell to the concrete mixture resulted decrease in compressive strength of normal concrete in each variation of the percentage. This is because the mixture of hazelnut shell is not strong enough to be a substitute for coarse aggregates, resulting in a decrease in the compressive strength of the concrete
\end{abstract}

Keywords: Concrete, hazelnut shell, Strong Concrete Press

How to Cite: Amri, D, Irwan, dan ardan, M. (2017), Pengaruh Penambahan Pecahan Kulit Kemiri Sebagai Pengganti Sebagian Agregat Kasar Pada Beton Terhadap Massa Dan Kuat Tekan Beton.JCEBT (Journal of Civil Engineering, Building and Transportation).3 (2): 88-96 


\section{PENDAHULUAN}

Kebutuhan

perumahan, perhubungan dan industri berdampak pada peningkatan kebutuhan bahan-bahan pendukungnya.Salah satu yang meningkat tajam adalah kebutuhan terhadap produk Beton.Beton dibuat dengan menggunakan Semen, pasir, kerikil, dan air. Dalam pembuatan Beton harus mempunyai sifat fisis dan mekanis sesuai dengan standar, misalnya SNI (Standart Nasional indonesia).

Beton merupakan bahan yang banyak digunakan dan menjadi unsur utama pada bangunan. Kelebihan beton antara lain memiliki kuat desak yang tinggi dibanding kuat tariknya, mudah dibentuk, tidak memerlukan perawatan khusus, bahan susun mudah didapat dari alam sekitar, dan lebih awet dibandingkan bahan bangunan lain. Semakin banyak beton digunakan sebagai bahan penyusun struktur beton, maka mendorong penelitian untuk mengembangkan material maupun cara pembuatan beton. (Siswadi 2007)

Pemakaian serat dalam campuran beton sudah cukup lama dilakukan, namun karena ketersediaannya semakin menurun maka dikembangkan berbagai jenis, salah satunya adalah kulit kemiri.Menurut data dari BPS provinsi Sumatera Utara, Sumut memproduksi kemiri sebesar 12.564,46 ton per tahun. Dimana berat kulit kemiri adalah $70 \%$ dari berat total kemiri sehingga total limbah kulit kemiri yang dihasilkan pertahun adalah sebesar 8795,122 ton. Kulit kemiri dalam percobaan ini berasal dari Kecamatan Juhar Kabupaten Karo, dimana Kabupaten Karo adalah pengasil kemiri terbesar kedua di Suamatera Utara setelah Dairi yaitu sebesar 1.706,40 ton per tahun.Kulit kemiri merupakan salah satu bahan tambah ataupun pengganti pada agregat yang akhir -akhir ini mulai diteliti dampak penggunaannya terhadap campuran pada beton.Penggunaan kulit kemiri ini dapat diperlakukan sebagai pengganti agregat kasar ataupun halus tergantung pada besar butiran cangkang kemiri yang digunakan.

Meskipun teknologi Beton telah terbukti kemampuannya, namun karena tuntutan konstruksi terhadap kuat tekan dan keawetan maka teknologi ini dapat ditingkatkan efektifitas kinerjanya dengan pendekatan: perbaikan atas mutu Beton dan penggabungan teknologi pembuatan berbagai komposit.

Sesuai dengan perkembangan teknologi, beberapa peneliti terus memperbaiki sifat sifat beton antara lain menambah serat ke dalam adukan yang disebut beton serat, yaitu beton yang dibuat dari campuran semen dengan agregat halus dengan bahan tambahan serat. Jenis serat yang dapat digunakan untuk memperbaiki sifat kurang baik dari beton adalah baja, plastik, kaca, karbon, dan serat alamiah (kulit kemiri).

Kemiri mengandung zat gizi dan nongizi.zat non gizi dalam dalam kemiri misalnya saponin, falvonoida dan polifenol. Banyak peneliti telah membuktikan bahwa ketiga komponen ini memiliki arti besar bagi kesehatan.Kandungan zat gizi mikro yang terdapat dalam kemiri adalah protein, lemak dan karbohidrat.Mineral dominan yang terdapat dalam kemiri adalah kalium, fosfor, magnesium, dan kalsium.Dalam kemiri juga terkandung zat besi, seng, tembaga dan selenium dalam jumlah sedikit. Kandungan penting lainnya adalah vitamin, folat, serta fitosterol yang dapat merusak enzim pembentuk kolesterol dalam hati sehingga dapat menghambat pembentukan kolesterol.

Pemanfaatan kulit kemiri menjadi alternatif baru untuk memperoleh beton serat yang diperoleh dari limbah kulit kayu. Hasil limbah kemiri diharapkan dapat meningkatkan dan memperbaiki sifat 
mekanik dan sifat fisis beton yang jauh lebih baik dari beton yang tanpa bahan tambah tetapi tidak mengurangi mutu.

maksud penelitian ini adalah untuk menggunakan kulit kemiri sebagai pengganti sebagian agregat kasar.

Tujuan dari penelitian ini adalah untuk mengetahui berapa besar pengaruh kulit kemiri sebagai pengganti sebagian agregat kasar terhadap massa dan kuat tekan beton.

Berdasarkan latar belakang yang telah diuraikan maka masalah yang dapat diangkat dalah penelitian ini adalah:

a. Apakah pengaruh kulit kemiri terhadap kuat tekan dan massa beton?

b. Bagaimana nilai kuat tekan beton sesudah mengalami penambahan kulit kemiri dengan variasi $0 \%, 10 \%, 20 \%$, dan $30 \%$ kulit kemiri?

Bagaimana massa beton sesudah mengalami penambahan kulit kemiri dengan variasi $0 \%, 10 \%, 20 \%$, dan $30 \%$ kulit kemiri?

Dalam penelitian yang penulis lakukan ini, ada beberapa masalah yang dibatasi agar cakupannya tidak terlalu luas, adapun batasan masalah tersebut adalah sebagai berikut:

1. Menguji kuat tekan dan massa beton K225.

2. Benda uji berbentuk kubus dengan ukuran panjang $15 \mathrm{~cm}$, lebar $15 \mathrm{~cm}$ dan tinggi $15 \mathrm{~cm}$.

3. Perawatan benda uji dengan cara perendaman.

4. Pengujian dilakukan pada umur 28 hari. 5. Alat untuk pengujian tekan beton mengguna alat Compression Testing Machine (CTM)

Untuk mendapatkan hasil penelitian yang sesuai dengan yang diharapkan dan dapat memperkecil kendala-kendala dalam pelaksanaannya. Maka diperlukan metode

penelitian pengumpulan data dilakukan dengan melakukan survey dan penyediaan material beton, pengujian material, rancangan campuran (Mix Design), Pembuatan benda uji (Kubus 15x15x15), Pemeliharaan, dan pengujian Kuat tekan setelah mencapai umur 28 hari. Disamping itu untuk mendukung terlaksananya penulisan hasil penelitian ini diperlukan beberapa literatur baik dari Jurnal, bukubuku serta e-bookyang berdasarkan dari internet yang berkaitan dengan penelitian ini.

\section{METODE PENELITIAN}

Bahan-bahan penyusun beton dalam penelitian ini adalah :

1. Semen yang digunakan semen portland, Semen Padang type I (Ordinary Portland Cement)

- SNI 15-3500-2004

2. Agregat halus pasir yang digunakan dari toko material yang diambil dari Kota Binjai.

3. Agregat kasar kerikil yang digunakan dari toko material yang berasal dari Kota Binjai.

4. Air dari PDAM LAB Beton Universitas Sumatera Utara.

\section{Pemeriksaan Bahan}

Pemeriksaan Kadar Lumpur Agregat Halus

1. Tujuan :Untuk memeriksa kadar lumpur pada pasir

2. Pedoman Penelitian : Kandungan lumpur tidak dibenarkan melebihi 5\% apabila melebihi maka pasir harus dicuci.

3. Hasil penelitian : Dari hasil pemeriksaan, kadar lumpur dalam pasir sebesar 2,21\%. Dinyatakan layak untuk penelitian.

\section{Pemeriksaan Analisa Ayakan Agregat Halus}


1. Tujuan Penelitian : Untuk menentukan gradasi dan modulus kehalusan pasir (FM).

2. Pedoman Penelitian :

FM

$=\frac{\sum \% \text { komulatif tertahan ayakan } 0,150 \mathrm{~mm}}{100}$

Dari hasil pemeriksaan analisa ayakan pasir tersebut didapat nilai $\mathrm{FM}=2,65$ termasuk dalam pasir sedang $(2,60<\mathrm{FM}<2,90)$.

\section{Pemeriksaan Berat Isi Agregat Halus}

1. Tujuan Penelitian : Untuk mengetahui berat isi pasir cara padat dan cara longgar.

2. Pedoman penelitian menunjukkan bahwa pasir yang dirojok atau cara padat lebih besar dari pada dengan pasir yang tidak dirojok atau dengan cara longgar.

3. Dari hasil pemeriksaan didapat:

a. Berat isi cara merojok $1310,35 \mathrm{~kg} / \mathrm{m}^{3}$

b. Berat isi cara tidak merojok : $1231,70 \mathrm{~kg} / \mathrm{m}^{3}$

\section{Pemeriksaan Berat Jenis Dan Absorpsi Agregat Halus}

1. Tujuan Penilitian : Untuk menentukan berat jenis dan penyerapan (absorpsi) pasir.

2. Pedoman Penelitian : Berat jenis kering < Berat jenis SSD < Berat jenis semu

3. Dari hasil penelitian didapat:

a. Berat jenis kering : $2,44 \mathrm{gr} / \mathrm{cm}^{3}$

b. Berat jenis SSD : $2,49 \mathrm{gr} / \mathrm{cm}^{3}$

c. Berat jenis semu :2,53 gr $/ \mathrm{cm}^{3}$

d. Absorpsi $: 1,5 \%$

4. $2,44<2,49<2,53$, pasir layak untuk percobaan.

Tabel 1.Kesimpulan Pemeriksaan Agregat Halus

Pemeriksaan Hasil

Kadar Lumpur $\quad 2,21 \%$
Analisa Ayakan $\quad 2,65$

Berat Isi (UW) $\quad 1231,70 \mathrm{~kg} / \mathrm{m}_{3}$

Berat Jenis (SSD) $\quad 2,49 \mathrm{gr} / \mathrm{cm}_{3}$

Absorpsi $\quad 1,5 \%$

Sumber : penelitian 2017

\section{Pemeriksaan Kadar Lumpur Agregat Kasar Batu sugai}

1. Tujuan Penelitian : Untuk memeriksa kadar lumpur batu sungai

2. Pedoman Penelitian : Kandungan lumpur pada agregat kasar tidak melebihi $1 \%$ apabila melebihi agregat harus dicuci.

3. Dari hasil penelitian kadar lumpur batu sungai sebesar $=0,73 \%$ sehingga batu sungai dapat digunkan dalam percobaan.

\section{Analisa Ayakan Agregat Kasar Batu sugai} 1. Tujuan Penelitian : Untuk memeriksa penyebaran gradasi dan menentukan modulus kehalusan (FM).

2. Pedoman Penelitian

$\mathrm{FM}=\frac{\sum \% \text { komulatif tertahan ayakan } 0,150 \mathrm{~mm}}{100}$

Agregat kasar yang dapat dipakai dalam campuran beton harus mempunyai modulus kehalusan (FM) antara 5,5 - 7,5. Dari hasil pemeriksaan diperoleh FM adalah 7,16 sehingga dapat digunakan dalam percobaan.

Pemeriksaan Berat Isi Agregat Kasar Batu Sugai

1. Tujuan Penelitian : Untuk menentukan berat isi batu kali dengan cara padat dan cara longgar.

2. Pedoman Penelitian : Dari hasil penelitian berat isi dengan cara padat atau merojok lebih besar dari pada berat isi dengan cara longgar atau tidak merojok.

3. Dari hasil penelitian diperoleh : 
a. Berat isi padat

$1785,40 \mathrm{~kg} / \mathrm{m}^{3}$

b. Berat isi longgar $\mathrm{kg} / \mathrm{m}^{3}$

\section{Pemeriksaan Berat Jenis dan Absorpsi Agregat Kasar}

1. Tujuan Penelitian : Untuk menentukan berat jenis dan penyerapan (absorpsi) air batu kali.

2. Pedoman penelitian : Berat jenis kering < Berat jenis SSD < Berat jenis semu

3. Dari hasil penelitian diperoleh :
a. Berat jenis kering
$: 2,53 \mathrm{gr} / \mathrm{cm}^{3}$
b. Berat jenis SSD
: $2,62 \mathrm{gr} / \mathrm{cm}^{3}$
c. Berat semu
: $\quad 2,65$
$\mathrm{gr} / \mathrm{cm}^{3}$
d. Absorpsi
$: 1,74 \%$

Tabel 2.Kesimpulan Pemeriksaan Agregat Kasar

Sumber : penelitian 2017

$\begin{aligned} & \text { Perencanaan Campuran Beton (Mix } \\ & \text { Design) }\end{aligned}$
(

Perencanaan campuran beton dengan perbandingan berat material dilakukan untuk menentukan kekuatan beton yang diinginkan. Dalam penelitian ini digunakan metode Development Of Environment (DOE). Adapun langkah-langkah dalam perencanaan campuran beton dengan metode DOE menurut SK SNI T - 15 - 1990 - 03 adalah sebagai berikut :

1. Menetapkan kuat tekan beton yang disyaratkan

2. Menetapkan nilai deviasi standar / nilai tambah

3. Menghitung nilai tambah (M)

4. Menghitung kuat tekan rata-rata perlu

5. Menetapkan jenis semen dan agregat

6. Menentukan faktor air semen

7. Menetapkan nilai slump

8. Menetapkan ukuran besar butir maksimum
9. Menetapkan kadar air bebas

10. Menghitung kebutuhan semen

11. Menetapkan kebutuhan semen yang sesuai

12. Menentukan persentase agregat halus dan kasar

13. Menghitung berat jenis SSD agregat gabungan

14. Menentukan berat jenis beton

15. Menghitung berat masing-masing agregat

16. Koreksi berat agregat dan berat air

\section{Penentuan Jenis dan Jumlah Benda Uji}

Direncanakan dalam penelitian ini jumlah benda uji masing-masing adalah 20 benda uji beton normal, 20 Benda uji Beton dengan Campuran kulit kemiri 10\% dan 20 Benda uji Beton dengan campuran kulit ke

\begin{tabular}{lll} 
mir & Pemeriksaan & Hasil \\
\cline { 2 - 3 } i & Kadar Lumpur & $0,73 \%$ \\
$\%$ & Analisa Ayakan & 7,16 \\
ser & Berat Isi (UW) & $1680,04 \mathrm{~kg} / \mathrm{m}_{3}$ \\
ta & Berat Jenis (SSD) & $2,62 \mathrm{gr} / \mathrm{cm}_{3}^{\prime m}$ \\
20 & ben \\
ben & Absorpsi & $1,74 \%$ \\
\hline
\end{tabular}

uji beton dengan campuran 30\% kulit kemiri, Cetakan benda uji berbentuk kubus $(15 \times 15 \times 15) \mathrm{cm}^{3}$.

\section{Perawatan (curing)}

Perawatan benda uji dilakukan dengan cara perendaman. Perawatan beton ini bertujuan untuk menjamin proses hidrasi semen dapat berlangsung dengan sempurna, sehingga retak-retak pada permukaan beton dapat dihindarai serta mutu beton yang diinginkan dapat tercapai. Selain itu kelembaban pemukaan beton juga dapat menambah ketahanan beton 
terhadap pengaruh cuaca dan lebih kedap air. Adapun cara perendamannya adalah sebagai berikut :

1. Setelah 24 jam maka cetakan beton kubus dibuka, lalu dilakukan perendaman terhadap sampel beton tersebut.

2. Perendaman dilakukan sampai umur beton 28 hari.

3. Sebelum beton direndam terlebih dahulu diberi nama pada permukaannya.

\section{Pengujian Kuat Tekan Sampel Beton}

Pengujian kuat tekan beton dilakukan pada umur beton 28 hari. Langkah-langkah pengujiannya adalah :

1. Kubus beton diangkat dari rendaman, kemudian dianginkan atau dilap hingga kering permukaan

2. Menimbang dan mencatat berat sampel beton, kemudian diamati apakah terdapat cacat pada beton sebagai bahan laporan

3. Pengujian Kuat Tekan dengan menggunakan mesin uji tekan beton

4. Meletakkan sampel beton ke dalam alat penguji, lalu menghidupkan mesin dan secara perlahan alat menekan sampel beton
Mencatat hasil kuat tekan beton untuk tiap sampelnya.

\section{Nilai Slump}

Perhitungan nilai slump pada beton pada dasarnya percobaan sederhana untuk mengetahui workability beton segar sebelum diaplikasikan dalam pengecoran. Percobaan dilakukan menggunakan kerucut abrams yang berdiameter atas $10 \mathrm{~cm}$ dan berdiameter bawah $20 \mathrm{~cm}$. Penelitian mengacu pada SNI 1972 : 2008. Pada pengujian slump beton normal direncanakan sebesar 6 - $18 \mathrm{~cm}$.

Tabel 3.Data hasil pengujian slump test beton normal

\begin{tabular}{lll}
\cline { 2 - 2 } $\begin{array}{l}\mathrm{Su} \\
\mathrm{mbe}\end{array}$ & Sampel & Nilai Slump $(\mathrm{cm})$ \\
$\mathrm{r} \quad \mathrm{C}$ & & \\
\cline { 2 - 3 } Hasi & $0 \%$ & 9 \\
$\mathrm{l}$ & $10 \%$ & 11 \\
pen & $20 \%$ & 13 \\
eliti & $30 \%$ & 14 \\
an & $30 \%$ & 12 \\
201 & Rata-rata & \\
$7)$ & &
\end{tabular}

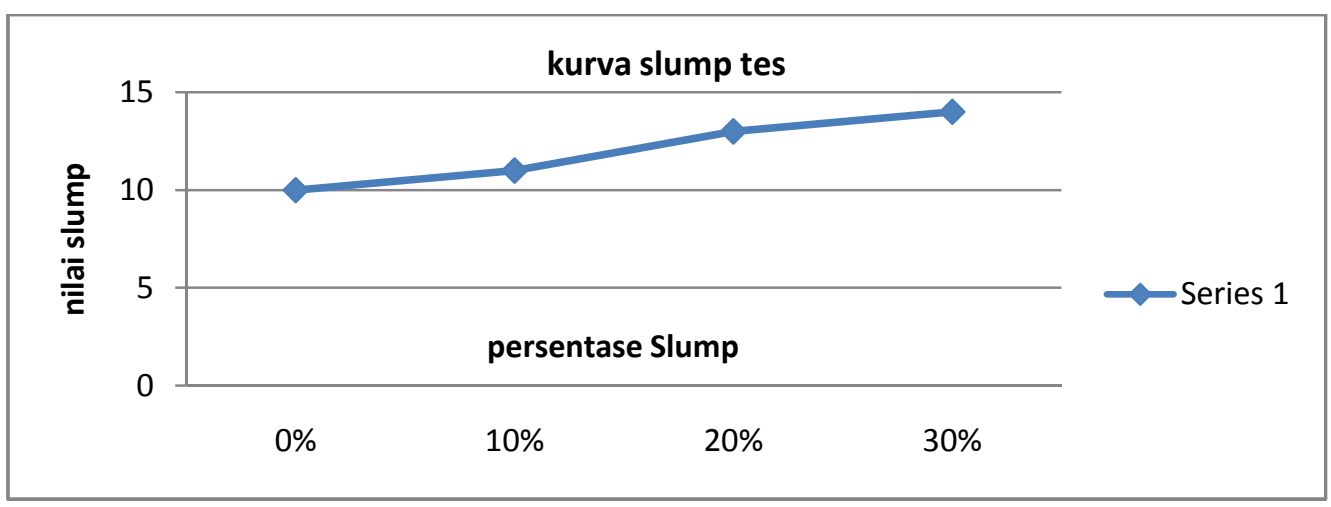

Gambar 1. Perbandingan nilai slump pada campuran beton

Sumber : penelitian 2017 


\section{Pengujian Kuat Tekan Benda Uji Kubus}

Pengujian kuat tekan beton bertujuan untuk mengetahui kuat tekan beton normal dengan karakteristik K 225 (dengan tambahan kulit kemiri). Pada penelitian ini, pengujian kuat tekan dilakukan setelah 28 hari dari pembuatan benda uji. Pada dasarnya pengujian kuat tekan mengacu pada SNI 03 - 1974 - 1990 "Metode Pengujian Kuat Tekan Beton". Apabila sesuai prosedur maka dapat dibandingkan kuat tekan beton normal dan beton campuran kulit kemiri.

Dari hasil pengujian kuat tekan diperoleh hubungan rata-rata dari beton normal dan beton yang dicampur dengan kulit kemiri. Massa beton normal memiliki rata-rata 828,57 Gram dan Massa rata-rata beton dengan campuran kulit kemiri 30\% adalah 515,31 Gram. Hasil dari kuat tekan ratarata beton normal sebesar $264,00 \mathrm{~kg} / \mathrm{cm}^{2}$ dan kuat tekan rata-rata beton $10 \%$ yang tambah dengan kulit kemiri sebesar 174,00 $\mathrm{kg} / \mathrm{cm}^{2}$, sehingga karakteristik beton yang awalnya K 225 berkurang menjadi menjadi $\mathrm{K}$ 175. Bahan-bahan material penyusun beton diperiksa dan dianalisa dengan baik sehingga perkiraan penetapan kuat tekan sedikit lebih besar dari yang direncanakan.

Penambahan kulit kemiri sebagai bahan tambahan beton mengakibatkan kurangnya daya ikat antara semen dan pasir. Dengan penyerapan yang besar ini sebelum dicampur kulit kemiri dikondisikan terlebih dahulu dalam kondisi jenuh agar tidak terjadi penyerapan yang besar terhadap air semen. Berat jenis kulit kemiri menyebabkan kulit kemiri naik kepermukaan beton saat proses pemadatan beton menggunakan vibrator. Hal ini menyebabkan permukaan beton menjadi tidak rata.Kulit kemiri yang naik kepermukaan menyebabkan kekuatan pada permukaan beton menjadi sangat lemah. Pada proses pengujian kuat tekan beton, permukaan beton yang mendapat tekanan lebih cepat mengalami retakan dan membuat daya tekan pada beton mengalami penurunan yang sangat besar.

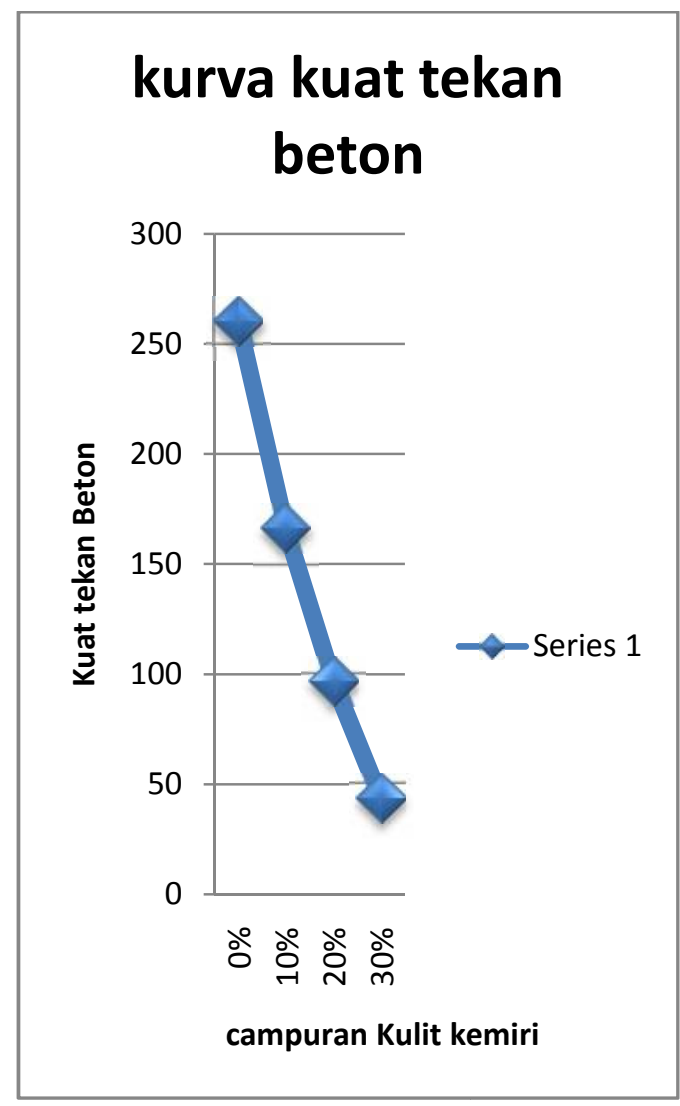

Gambar 2.kurva kuat tekan

Sumber : penelitian 2017

\section{KESIMPULAN}

Berdasarkan hasil penelitian dan pembahasan yang telah diuraikan sebelumnya, dapat ditarik kesimpulan sebagai berikut : 


\section{Penambahan Kulit kemiri pada DAFTAR PUSTAKA}

campuran beton mengakibatkan penurunan kuat tekan beton normal disetiap variasi persentasenya.Hal ini di sebabkankurangnya daya ikat antara semen dan pasir.Berat jenis kulit kemiri menyebabkan kulit kemiri naik kepermukaan beton saat proses pemadatan beton menggunakan vibrator. Hal ini menyebabkan permukaan beton menjadi tidak rata.Kulit kemiri yang naik kepermukaan menyebabkan kekuatan pada permukaan beton menjadi sangat lemah. Pada proses pengujian kuat tekan beton, permukaan beton yang mendapat tekanan lebih cepat mengalami retakan dan membuat daya tekan pada beton mengalami penurunan yang sangat besar. Massa pada beton juga mengalami perubahan yang cukup besar.Hal ini disebabkan berat kulit kemiri yang jauh lebih ringan dibandingkan berat kerikil yang membuat berat beton menjadi lebih ringan.
Biduan Manahan Nainggolan dan Alkhafi Maas Siregar, (2015), "PENGARUH PENAMBAHAN CANGKANG KEMIRI TERHADAP KUAT TEKAN DAN RETAKAN BETON PASCA BAKAR", Jurnal Einsten Prodi Fisika FMIPA Unimed,1 (5): 9-14

Daud Patabang, "analisis nilai kalor secara eksperimental dan teoritik dari briket arang kulit kemiri"

Departemen PU Republik Indonesia.1971.Peraturan Beton Bertulang Indonesia. Bandung: Yayasan Lembanga Penyidik Maalah Bangunan

Frederick Raymond, Tito Sucipto, Irawati Azhar, "pengaruh perlakuan pengarangan dan penambahan partikel kemiri terhadap kualitas paving block"

"Kandungan Gizi Dan Manfaat Kemiri bagi kesehatan",http://buahansehat.blogspot.co.id /2014/03/khasiat-dan-kandungan-gizikemiri.html

"Kasiat Dan Kandungan Kemiri", https://minyakkemiriasli. wordpress.com /2013/02/26/ khasiat-dan-kandungankemiri/ (diakses tanggal 12 juni 2017)

Mulyono, Try,2003. Teknologi Beton.Yogyyakarta: Penerbit Andi

Risdiyanto, Yudi, "kajian tekan beton dengan perbandingan volume dan perbandingan berat untuk produksi beton massa menggunakan agregat kasar batu pecah merapi (studi kasus pada proyek pembangunan sabo dam)" 
Sandro Janesra Gurning dan Nursyamsi, "pengaruh penambahan abu sekam padi dan cangkang kemiri terhadap sifat mekanis beton"

SNI 03-1974-1990. Metode Pengujian Kuat Tekan Beton, SNI 03-2834-2000. Tata Cara Pembuatan Rencana Campuran Beton Normal. Badan Standardisasi Nasional, SNI 15-3500-2004. Semen Portland Campur. 